\title{
The Relationship between Organizational Politics, Job Satisfaction and Turnover Intention in the Maritime-Related Agencies in the East Coast of Peninsular Malaysia
}

\section{Juhaizi Mohd Yusof, Siti Nur 'Atikah Zulkiffli, Siti Falindah Padlee, and Nurul Ayuni Yusof}

School of Maritime Business \& Management, Universiti Malaysia Terengganu, Terengganu, Malaysia

\section{Abstract}

The study aimed to examine the relationship between organizational politics, employee's job satisfaction and turnover intention in the public maritime-related

Corresponding Author: Juhaizi Mohd Yusof juhaizi@gmail.com

Received: 7 August 2018 Accepted: 15 September 2018 Published: 22 October 2018

Publishing services provided by Knowledge

(c) Juhaizi Mohd Yusof et al. This article is distributed under the terms of the

Attribution License, which permits unrestricted use and redistribution provided that the original author and source are credited.

Selection and Peer-review under the responsibility of the ICE-BEES 2018 Conference Committee. agencies in the east coast of Peninsular Malaysia. The study utilized cross sectional research design. An enumeration of entire population (census) was conducted on 140 employees from Royal Malaysian Custom and Department of Fisheries in Terengganu. Data for the study were collected through questionnaire. 140 set of questionnaire were distributed and 109 copies were returned. Preliminary analyses were performed to ensure violation of assumptions of normality, linearity and homogeneity which enables us to analyze the data with the aid of Statistical Package for Social Science (SPSS) and SmartPLS softwares. The findings revealed a significant association between organizational politics, employee's job satisfaction and turnover intention. The study therefore recommended that the agencies should actively focus on positive political behaviour that will fuel workers' job satisfaction and they should ensure proper pay structure including pay performance and other bonuses that will lead to employee job satisfaction and reduce turnover intention. Finally, the findings of this study could assist the public maritime-related agencies in the area of organizational politics that would promote employee job satisfaction.

Keywords: organizational politics, job satisfaction, turnover intention

\section{Introduction}

Organizations are social entities that individual and group use variety of strategies that include personal conflict to achieve their benefit, goals and also to promote and protect their self-interest in the organization [1]. Organizational politics (OP) is a common 
situation in organizational life, which stems out from the use of power by authority or top management and also about the how individuals use their power and influences the activities of the systems [2]. According to [3], organizational politics is the management of power by using the way that not approved by organization or use unsanctioned influence to get or to reach their own aim or goal. The importance of organizational politics lies in its potential consequences and effect on work outcomes. Many scholars argued that politics often interferes with normal organizational processes (e.g., decision making, promotion, and rewards) and affect productivity and performance on individual and organizational levels [4]. Many studies related to OP have been conducted in the public sector but in fact they were conducted mainly at universities or they used mixed samples of private and semipublic agencies like hospitals and government-owned industries [4]. Furthermore, most studies of OP were conducted in the Western context. In most countries, wages of public servants are lower than those of private sector employees, promotion is slower, and rewards are generally not related to work outcomes [5]. Nevertheless, public organizations usually offer a stable work environment and higher job security. The internal politics of public agencies could possibly have a unique effect on the employees which still remain unclear and deserves more attention. Therefore, it is the aim of this study to examine the impact of OP to the job satisfaction and turnover intention in the public maritimerelated agencies in the east coast of Peninsular Malaysia to contribute to the existing literature of OP.

\section{Literature Review}

\subsection{Organizational politics}

Organisational politics is management of power that influence a variety of action or act to reach the good outcome to the worker $[6,7]$. [8] defined perception of organizational politics as the degree that individuals view an environment of their work as the politics which are unfair. According to [9], there are three aspects of organization politics i.e. general political behavior which related to worker perceptions of their coworkers engaging in political activities. It is also the behavior of individuals that act in a self-interest manner to gain valued outcomes. Another aspect is pay and promotion representing organization behaving politically through the policies that enacts its. The last aspect is go along to get ahead which influenced to tactics such as placing oneself purposely by agreeing with those in power or a lack of action by individuals in order to 
locked valued outcomes. [10] argued that using power also can influence the decision making, or in giving ideas to reach the goal and productivity of company or individuals itself. For example, organizational politics influence the decision of the management such as supervisor rating in performance appraisal of the employees and when giving idea in organization. [11] stated that individual will feel pressure derived from factors such as perceptions of organizational politics which impacting on job satisfaction and turnover intention of the employees. In addition, in a much positive view in political behaviour of organizations, it regards it as an unavoidable part of the need for groups and individuals to function in a collective context $[12,13]$. It is supported by $[14]$, in which managers use politics as a functional tool in organization to make sure all works are done.

\subsection{Job satisfaction}

Job satisfaction can be defined as an individual's feelings about their work and their attitudes towards various aspects of their work, as well as attitudes and perceptions that may influence the degree of fit between the individual and the organization [15, 16]. [17] state that good fit between an employee and his or her work environment is important because the work environment such as organizational culture will be a predictor of the employee's job satisfaction in order to reach a high level of jobsatisfaction. According to [18], research has indicated that job satisfaction is dependent on organisational variables such as structure, size, pay, working conditions and leadership, which represent the organisational climate and does not come about in isolation. [19] reiterates that a person with high job satisfaction appears to hold positive attitudes, and one who is dissatisfied to hold negative attitudes towards their job. Job satisfaction also a major predictor of employee burnout, turnover and intention to quit [20]. When employees are unsatisfied with their work environment, they may not be willing to forfeit their personal interests to help the organization thus it will decrease the performance of organization [21]

\subsection{Turnover intention}

[22] defined turnover intention as the individual behavior across the membership boundary of an organization, while [23] defined turnover intention as a mental decision that had been taken by an individual with respect to his employment whether to continue or leave their jobs. In addition, [24] defined employee turnover intention as 
"individuals" own estimated probability (subjective) that they are permanently leaving the organization at some point in the near future. Turnover intention phenomena often occur in an organization's enterprise whether in the private or government sector. This happens often associated with the company's environmental conditions, given the pressures of work, and a variety of complaints and the reasons given by the employees. [25] argue that when employee cannot get happiness from their work then the dissatisfaction of job is high, they will look for other opportunities which can give them happiness or satisfaction. Hence job satisfaction is viewed as significant predictors of turnover intention. Intention represents or it can be interpreted as an act of conscious and deliberate control to leave the organization. Meanwhile, turnover was previously understood as termination contract of the employment. [26] argue that intention is a predictor of actual behaviour. Intention have significant effect to the actual behaviour in order to leaving or staying at the organization [27]. If symptoms of turnover intentions occur, it negatively affects the organization itself. This is because, when the employee has terminated the contract of work in an organization then the company will incur a loss in terms of labour, the cost of hiring, the cost of training new employees and so on.

\subsection{Relationship between organizational politics, job satisfaction and turnover intention}

There are many research conducted to examine the relationship between organization politics and job satisfaction in various industry or sector. A study by [28] on 125 individuals working in diverse organizations in Senegal found that employees perceiving higher level of organizational politics were less satisfied with their job and reported lower level of organizational citizenship behaviour and organizational commitment. A similar study by [29] on 300 employees of the commercial banking sector in Sri Lanka found that perceived organizational politics impact negatively on job satisfaction. Studies in the public sector also found a similar result. [30] examined the relationship between perception of organizational politics, job attitudes, and several other work outcomes among 303 public sector employees in Israel. Perception of organizational politics was found to have had a negative relationship with job attitudes (e.g., job satisfaction and organizational commitment), a positive relationship with intention to leave the organization (exit), and a stronger positive relationship with negligent behavior (neglect). [31] conducted a study on 200 randomly selected employees of 
Babcock University Ilishan, Ilishan - Remo, Ogun State, Nigeria to examine the relationship between organizational politics and turnover intention. The findings revealed a high and positive correlations between organizational politics and turnover intention, work efficiency and organizational commitment. In simple words, the higher of organizational politics will consequently results in the higher of turnover intention in the organization.

Based on the above literature review, the study forwarded three hypotheses as follows: -

$\mathrm{H}_{1}$ : There is a significant positive relationship between organisational politics and turnover intention

$\mathrm{H}_{2}$ : There is a significant negative relationship between organisational politics and job satisfaction

$\mathrm{H}_{3}$ : There is a significant negative relationship between job satisfaction and turnover intention

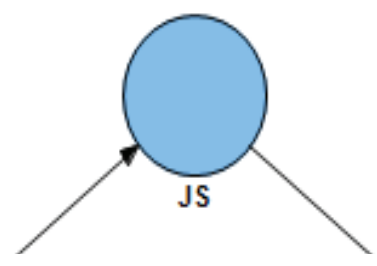

$\mathrm{H} 2$

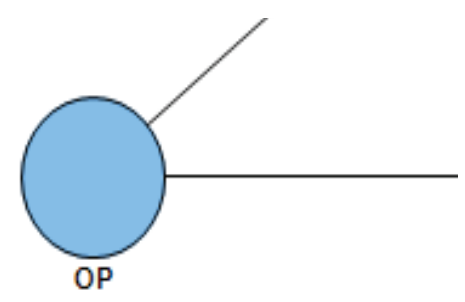

H3

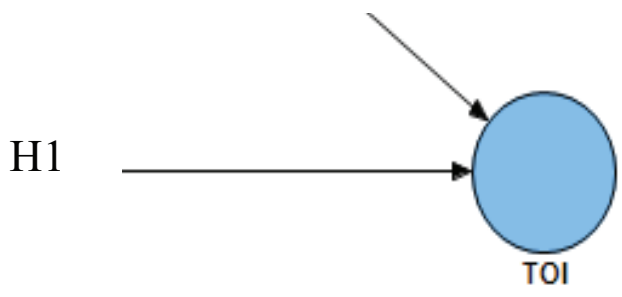

Figure 1: Theoretical framework.

\section{Methodology}

A quantitative approach was adopted to examine the relationship between organizational politics, job satisfaction and turn over intention in the public maritime-related agencies i.e. Royal Malaysia Custom and Fisheries Department in Terengganu, in the east coast of Peninsular Malaysia as the target population. These organizations were 
selected based on their proximity, accessibility and their willingness to take part in the study. There are 80 of employees at Royal Malaysia Custom and 60 employees at Fisheries Department. The study conducted a numeration of the entire population (census) to collect data because the target population/sampling frame (140 employees) could not be reduced to select a sample, due to low response rate of the questionnaire method [32]. Three data collection instruments were utilized for the study: 1) Perception of Organisational Politics scale (POP) developed by [9] and 2) Abridged Job In General (aJIG) developed by [33] and 3) Turnover Intention [34].

Demographic questionnaires were also created to obtain personal information of the respondents. All the instruments were combined to form a single survey instrument for this study. The survey questionnaire consisted of 4 parts i.e. Part 1: Demographic information; Part 2: Perception of Organisational Politics questionnaires (12 items); Part 3: Abridged Job In General (8 items); and Part 4: Intention to leave (4 items). 140 questionnaires were distributed to the respective agencies, and 109 questionnaires were returned constituted a 77.9\% returned rate. After data screening, 106 samples were retained for further analysis. On average, the majority of the employees were between $31-40$ years old and the majority of respondents have been working with their current organisation between 5-10 years. The result of the demographic analysis is presented in Table 1 of this study.

TABLE 1: Demographic analysis.

\begin{tabular}{|c|c|c|c|c|c|}
\hline Demographics features & Frequency & Percent & Demographics features & Frequency & Percent \\
\hline Gender & & & Period with organisation & & \\
\hline Female & 51 & 48.1 & Less than a year & 6 & 5.7 \\
\hline Male & 55 & 51.9 & 1 - 5 years & 22 & 20.8 \\
\hline Total & 106 & 100.0 & $5-10$ years & 46 & 43.4 \\
\hline Age & & & Over 10 years & 32 & 30.2 \\
\hline Less than 20 & 1 & 0.9 & Total & & \\
\hline 21-30 years old & 29 & 27.4 & Job type & & \\
\hline $31-40$ years old & 50 & 47.2 & Office administration & 73 & 68.9 \\
\hline 41-50 years old & 17 & 16.0 & Operation/Shift & 13 & 12.3 \\
\hline 50 and above & 9 & 8.5 & Others & 20 & 18.9 \\
\hline Total & 106 & 100 & Total & 106 & 100 \\
\hline \multicolumn{6}{|l|}{ Education } \\
\hline Secondary education & 44 & 41.5 & & & \\
\hline Tertiary education & 37 & 34.9 & & & \\
\hline Others & 25 & 23.6 & & & \\
\hline Total & 106 & 100 & & & \\
\hline
\end{tabular}




\subsection{Data analysis}

In this study, Statistical Package for Social Sciences (SPSS) 18.0 and SmartPLS software package 2.0 were used for data analyses. The choice of PLS-SEM in this study is based on the fact that it offers a simultaneous test of an entire system of variables in a hypothesized model and thus enables assessment of the extent to which the model is consistent with the data. PLS has the advantage that it "involves no assumptions about the population or scale of measurement" [35]. Therefore, PLS was chosen to establish the construct, measurement and structural models of this study. PLS provides the measurement model, which includes an assessment of the reliability and validity of the measures and an evaluation of the structural model, which describes the relationship between dependent and independent variables by generating the estimates of standardized regression coefficients for the model [36]. PLS requires a relatively small sample size [37]. For example, [38] recommended that 20 cases per a dependent variable are suitable to test the statistical model. A well-known standard for PLS sample size developed by [39] and [40] is to consider the number of structural paths and dependent variables. Specifically, [39] suggested ten times the largest number of structural paths directed at a particular construct in the inner path model. [40] suggested ten times the number of predictors for a dependent variable that includes the largest number of indicators. Thus, the number of valid samples in this research, 106 , is sufficient to use PLS and in turn, to obtain reliable results.

\subsection{Results for the measurement model}

The measurement model was evaluated by assessing the convergent validity, which is measured by loading, the average variance extracted (AVE) and the composite reliability $(C R)$ result. The result revealed good items loading above the recommended threshold (0.5) by [41]. The items which showed lower than 0.5 were dropped. The result of the average variance extracted (AVE) indicates a value above 0.5 recommended threshold [41]. The summary of the measurement model in this study is presented in Table 2.

In order to test the constructs' convergent and discriminant validity, additional analyses were run by comparing the AVE and correlation between constructs. A comparison of the correlation with the square root of AVE (as shown in bold in Table 3) indicates that the correlation between two constructs is less than the square root of AVE of both 
TABLE 2: Summary of Constructs Items Loadings, AVE, CR, and R-Square.

\begin{tabular}{|c|c|c|c|c|c|}
\hline Construct & Indicator & Loadings & $C R$ & AVE & $\mathrm{R}^{2}$ \\
\hline Organisational politics & $\mathrm{OP}_{1}$ & 0.683 & 0.888 & 0.501 & \\
\hline \multirow[t]{7}{*}{ politics } & $\mathrm{OP}_{2}$ & 0.793 & & & \\
\hline & $\mathrm{OP}_{3}$ & 0.622 & & & \\
\hline & $\mathrm{OP}_{4}$ & 0.575 & & & \\
\hline & $\mathrm{OP}_{5}$ & 0.770 & & & \\
\hline & OP7 & 0.683 & & & \\
\hline & OP8 & 0.778 & & & \\
\hline & OP10 & 0.732 & & & \\
\hline Job satisfaction JoB SATI & $J \mathrm{G}_{2}$ & 0.763 & 0.901 & 0.768 & 0.164 \\
\hline \multirow[t]{3}{*}{ satisfaction } & $\mathrm{JIG}_{3}$ & 0.881 & & & \\
\hline & $J G_{5}$ & 0.904 & & & \\
\hline & JIG7 & 0.780 & & & \\
\hline Turnover lintention & TOl1 & 0.880 & 0.908 & 0.700 & 0.324 \\
\hline \multirow[t]{2}{*}{ Intention } & $\mathrm{TOl} 2$ & 0.900 & & & \\
\hline & $\mathrm{TOl} 3$ & 0.848 & & & \\
\hline
\end{tabular}

groups. This means that discriminant validity exists [42]. Therefore the results supported adequate convergent and discriminant validity of the constructs in the model.

TABLE 3: Latent variable inter-correlation, and square root of AVE for assessing convergent and discriminant validity.

\begin{tabular}{|l|c|c|c|}
\hline Constructs & OP & JS & TOI \\
\hline OP & $\mathbf{0 . 7 0 8}$ & & \\
\hline JS & -0.405 & $\mathbf{0 . 8 3 4}$ & \\
\hline TOI & 0.4121 & -0.525 & 0.876 \\
\hline
\end{tabular}

Note: The diagonal elements (in bold) are the square root of Average Variance Extracted.

Other non-diagonal elements are latent variable correlations.

\subsection{Results for the structural model and hypotheses}

A satisfactory evaluation of the structural model in PLS must consist of three indexes including path coefficients, squared multiple correlations $\left(R^{2}\right)$, and t-value. The high values of $R^{2}$ verify the good fitness and validity of the built model [36]. Threshold value of $0.25,0.5$ and 0.7 are often used to describe a weak, moderate, and strong coefficient of determination [43]. As shown in Table $2, R^{2}$ for turnover intention was 0.324 , which meant that organizational politics and job satisfaction jointly explained about $32.4 \%$ of variance of turnover intention. 
Hypothesis testing is conducted to analyse the cause-effect relationships (causality) among the variables in the model based on the value of the critical ratio (CR). In terms of PLS-SEM, CR is known as the t-stat value. T-values are obtained through the bootstrap routine and must be more than 1.96 [40]. If t-stat values higher than 1.96 (sig. 5\% two-tailed) means that the hypothesis is supported. The results of hypothesis testing can be observed in Table 4 . In this research, the results supported positive impact of organisational politics on turnover intention. Therefore, the first hypothesis of this research was supported significantly. PLS analysis showed that organisational politics and job satisfaction jointly accounted for about $32.4 \%$ of the variance in turnover intention (see Table 2). Furthermore, this research elaborated the relationship between organisational politics and job satisfaction. Based on the results of the second hypothesis $\left(\mathrm{H}_{2}\right)$, a significant negative relationship of organisational politics and job satisfaction was found in this study. The results also showed that job satisfaction has a negative relationship with intention to leave and the third hypothesis $\left(\mathrm{H}_{3}\right)$ of this research was supported significantly. Table 4 presents a summary of results of the hypotheses testing.

TABLE 4: Summary of hypotheses testing.

\begin{tabular}{l|c|c|c|}
\hline Hypothesis & Path Co-efficient & T- Statistics & $\begin{array}{c}\text { Hypothesis } \\
\text { Testing }\end{array}$ \\
\hline $\mathrm{OP} \rightarrow \mathrm{TOI}\left(\mathrm{H}_{1}\right)$ & 0.239 & 3.011 & Supported \\
\hline $\mathrm{OP} \rightarrow \mathrm{JS}\left(\mathrm{H}_{2}\right)$ & -0.405 & 4.628 & Supported \\
\hline $\mathrm{JS} \rightarrow \mathrm{TOI}\left(\mathrm{H}_{3}\right)$ & -0.429 & 5.332 & Supported \\
\hline
\end{tabular}

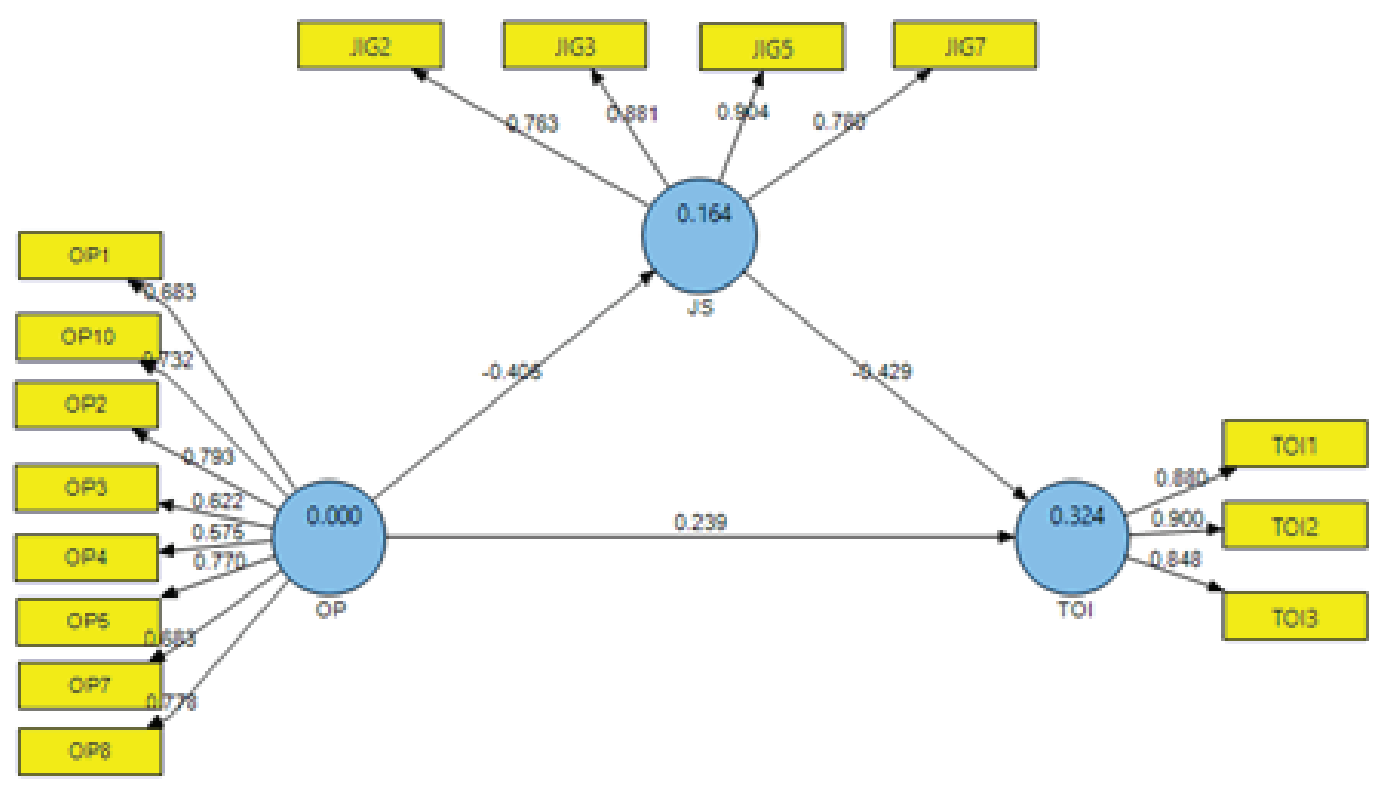

Figure 2: Structural model. 


\section{Conclusion}

The results of this study were found to be consistent with the study by [28-31]. Organizational politics were found to be positively related with turnover intention and negatively related to job satisfaction. The higher the perception of organizational politics by the employees means the lower job satisfaction and the higher the turnover intention of the employees. It can be concluded that both public and private sectors showed similar results. The study therefore recommended that the public agencies should actively focus on positive political behaviour that will fuel workers' job satisfaction and they should ensure proper pay structure including pay performance and other bonuses that will lead to employee job satisfaction and reduce turnover intention. Finally, the findings of this study could assist the public maritime-related agencies in the area of organizational politics that would promote employee job satisfaction. Future study on the impact of organizational politics on the employees' outcome should extends on larger public organizations to obtain a clearer understanding on the importance of organizational politics to the organizational outcomes.

\section{References}

[1] Kacmar, K. M., Bozeman, D. P., Carlson, D. S., \& Anthony, W. P. (1999). An examination of the perceptions of organizational politics model: Replication and extension. Human relations, 52(3), 383-416

[2] Danish, R. Q., Humayon, A. A., Aslam, N., Usman, A., \& Tariq, M. I. (2014). Employee ' s Perceptions of Organizational Politics and Stress at Workplace区; A Comparative Study of Public and Private Sector Universities. Research Journal of Recent Sciences, $3(7), 44-52$.

[3] Mayes, B. T., \& Allen, R. W. (1977). Toward a definition of organizational politics. Academy of Management Review, 2, 672-678

[4] Vigoda, E. (2000). Organizational Politics, Job Attitudes, and Work Outcomes : Exploration and Implications for the Public Sector. Journal of Vocational Behavior, 57, 326-347. https://doi.org/10.1006/jvbe.1999.1742

[5] Rainey, H. G. (1991). Understanding and managing public organizations. San Francisco; Jossey-Bass

[6] Kipnis, D., Schmidt, S.M. and Wilkinson, I. (1980), "Intraorganizational influence tactics: exploration in getting one's way", Journal of Applied Psychology, Vol. 65, Pp. 440-52. 
[7] Pfeffer, J. (1992), Management with Power, Harvard Business School Press, Boston, MA.

[8] Ferris, G.R., Russ, G.S. and Fandt, P.M. (1989), "Politics in organizations", in Giacalone, R.A. and Rosenfeld, P. (Eds), Impression Management in the Organization, Erlbaum, Hillsdale, NJ, pp. 143-70.

[9] Kacmar, K.M. and Ferris, G.R. (1991), "Perceptions of organizational politics scale (POPS): development and construct validation", Educational\&Psychological Measurement, Vol. 51, pp. 193-205.

[10] Brandon, R., \& Seldman, M. (2004). Survival of the savvy: High-integrity political tactics for career and company success. New York: Free Press.

[11] Terrick , L. \& LaRocco , J. ( 1987 ). Understanding, prediction and control as moderators of the relationship between perceived stress, satisfaction and psychological well-being . Journal of Applied Psychology , 72, 538-543

[12] Martin, J. (2001). Organizational Behavior. 2nd edition. Thomson Learning Publication, New York

[13] Jam, A. F., Khan, I. T., \& Zaidi, H. P. (2011). Political Skills Moderates the Relationship between Perception of Organizational Politics and Job Outcomes. Journal of Educational and Social Research, 1(4),90-98.

[14] Pfeffer, J. (1981), Power in Organizations, Boston, MA: Pittman.

[15] Ivancevich J., Matteson M., (2002), Organizational Behavior and Management, McGraw-Hill

[16] Spector P. (1997) Job Satisfaction. Application, Assessment, Causes and Consequences. Sage Publications, London.

[17] Taris R. \& Feij F.A. (2001) Longitudinal examination of the relationship between supplies-values fit and work outcomes. Applied Psychology 50 (1), 52-81.

[18] Sempane, M.E., Rieger, H.S. and Roodt, G. (2002). "Job Satisfaction in Relation to Organizational Culture", Journal of Industrial Psychology, Vol 28, No. 2, pp 23-30.

[19] Robbins SP, Odendaal A, Roodt G (2003). Organizational behavior (9th ed.) Cape Town. Prentice-Hall International.

[20] Siu O.L. (2001) Organizational climate and psychological distress among general and psychiatric nurses in Hong Kong. In Organizational Psychology and Health Care at the Start of a New Millennium (de Jonge J., Vlerick P., Bussing A., Schaufeli W.B. eds), Rainer Hampp Verlag, Mering, pp. 39-54.

[21] LePine, J.A., \& VanDyne, L. (2001). Voice and cooperative behavior as contrasting forms of contextual performance: Evidence of differential relationships with big five 
personality characteristics and cognitive ability. Journal of Applied Psychology, 86 (2), 326-336.

[22] Price, J.L. (1997). Handbook of Organizational Measurement. MCB University Press, Bradford.

[23] Jacobs, E. \& Roodt, G. (2007). The development of a knowledge sharing construct to predict turnover intentions. Aslib Proceedings: New Information Perspectives, 59(3), 229-248.

[24] Matthias H.J. Gouthier, Miriam Rhein, (2011). Organizational pride and its positive effects on employee behaviour. Journal of Service

[25] Wright, T.A. and Bonett, D.G. (2007). Job satisfaction and psychological well-being as non-additive predictors of workplace turnover. Journal of Management, 33(2), $141-60$.

[26] Sommer, L. and M. Haug (2010), Intention as a cognitive antecedent to international entrepreneurship-understanding the moderating roles of knowledge and experience, International Entrepreneurship and Management Journal, 7:1, 111-142.

[27] Cotton, J. L., \& Turtle, J. M. (1986). Employee turnover: A meta-analysis and review with implications for research. Academy of Management Review, 11, 55-70.

[28] Faye, K., \& Ye, L. (2014). The Impact of Job Satisfaction in the Relationships between Workplace Politics and Work Related Outcomes and Attitudes: Evidence from Organizations in Senegal. International Journal of Business and Management, 9(5), 160-168. http://doi.org/10.5539/ijbm.v9n5p160

[29] Kodisinghe, K.A.M.S., 2010. Impact of perceived organizational politics on employees' job satisfaction in the commercial banking sector of Sri Lanka, In: Proceedings of the 1st International Conference on Business and Information, University of Kelaniya.

[30] Vigoda, E. G., \& Cohen, A. (2002). Influence tactics and perceptions of organizational politics: A longitudinal study. Journal of Business Research, 55, 311-324

[31] Gbadamosi, L., \& Chinaka, N. J. (2011). Organizational politics, turnover intention and organizational commitment as predictors of employees' efficiency and effectiveness in academia. Proceedings of Informing Science \& IT Education Conference.

[32] Cooper, D. R. \& Schindler, P.S. (1998). Business Research Methods 6th ed. New York: McGraw-Hill.

[33] Russell, Steven S., Spitzmüller, Christiane. , Lin, Lilly, F. , Stanton, Jeffrey, M., Smith, Patricia, C. Elronson, Gail, H. (2004). Shorter can Also be Better: The Abridged Job in 
General Scale. Educational and Psychological Measurement, 64(5), 878-893. http: //doi.org/10.1177/0013164404264841

[34] Jaramillo, F., Grisaffe, D., B., Chonko, Lawrence B., \& Roberts, J., A. (2009). Examining the impact of servant leadership on salesperson's turnover intention, Journal of Personal Selling \& Sales Management; 29(4), 351-365.

[35] Fornell, Claes\& Fred L. Bookstein (1982). Two structural Equation Models: LISREL and PLS Applied to Consumer Exit-Voice Theory. Journal of Marketing Research, XIX (November), 440-452

[36] Götz, 0.; Liehr-Gobbers, K. ; Krafft, M. (2010): Evaluation of Structural Equation Models using the Partial Least Squares (PLS) Approach, in: Esposito Vinzi, V.; Chin, W.; Henseler, J.; Wang, H. (Eds.): Handbook of Partial Least Squares - Concepts, Methods and Applications, Springer, Heidelberg et al., S. 691-711.

[37] Marcoulides, George A., Chin, Wynne W., Saunders, C. (2009). a Critical Look At Partial Least Squares Modeling (PIs). Mis Quarterly, 33(1), 171-175. http://doi.org/ Article

[38] Chin, W. W. (2010).Bootstrap cross-validation indices for PLS path model assessment. Handbook of Partial Least Squares (pp. 83- 97). Springer Handbooks of Computational Statistics

[39] Barclay, D. W., Higgins, C., \& Thompson, R. (1995). The partial least squares approach to casual modeling: Personal computer adoption and use as illustration. Technology Studies, 2(2), 285-309

[40] Chin, W. W. (1998). The partial least squares approach for structural equation modeling. In G. A. Marcoulides (Ed.), Modern methods for business research (pp. 295-336). London: Lawrence Erbaum Associates.

[41] Hair, J., Black, B. Babin, B., Anderson, R. and Tatham, R. (2006). Multivariate Data Analysis (6th edition). Upper Saddle River, NJ: Prentice-Hall.

[42] Hulland, J. S. (1999). Use of partial least squares (PLS) in strategic management research: A review of four recent studies. Strategic Management Journal, 20(4), 195-204.

[43] Hair, J. F., Hult, G. T. M., Ringle, C. M., \&Sarstedt, M. (2013). A Primer on Partial Least Squares Structural Equation Modeling (PLS-SEM). Thousand Oaks: Sage. 